\title{
REVIEW ON BIOREMEDIATION PROCESS OF A CRUDE OIL IN CONTAMINATED SOIL BY LEACHING AND TOXICITY ASSESSMENTS
}

\author{
Mosstfa Maaroof, Sukru Dursun \\ Environmental Engineering Department, Engineering Faculty, Selçuk University, Konya, Turkey; \\ *Corresponding author: Sukru Dursun, email: mmaaroof@ selcuk.edu.tr; sdursun@ selcuk.edu.tr;
}

Received May, 2018; Accepted June, 2018; Published July, 2018;

DOI: https://doi.org/10.31407/ijees8404

UOI license: http://u-o-i.org/1.01/ijees/94882886

\begin{abstract}
The most widely used chemicals in society today are Petroleum products. With the massive quantity of fuel required to power automobiles and heat homes, and the number of times each gallon of petroleum is stored, transported, or transferred, accidents and leakages are unavoidable. All the results of Petroleum contamination from leaking aboveground and underground storage tanks, spillage during transport of petroleum products, abandoned manufactured gasoline sites, other unplanned releases, and current industrial processes. As petroleum contains hazardous chemicals such as benzene, toluene, ethylbenzene, xylenes, phenols and naphthalene, this contamination can be hazardous to the health of plants, animals, and humans. Hydrocarbons (HC) entrance into the soil environment can take place by pipeline blow-outs, road accidents, leaking of underground storage tanks, land farming fields and uncontrolled landfilling. When released on the soil surface, HC adsorb on the organo-mineral matter (OMM) of the soil, The Removal of HC from soils can be performed using biological treatments like bioremediation if the environmental conditions are optimum (temperature, soil moisture, nutrients). The presence of high rates of organic matter and clay may affect the extent of biodegradation due to a priming effect on microbial communities and to a decrease of accessibility to microorganisms High concentrations of $\mathrm{HC}$ can eliminate vegetation due to their phytotoxic properties. Most country's environmental legislations are now focused on treatment and disposal of polluted soils, especially with respect to hazardous waste management. As there are no universal $\mathrm{HC}$ cleanup standards, the remediation end points might be in the evaluation of the impact of residual HC on the soil ecosystem and on the water quality. Petroleum-contaminated soil is currently treated using three processes: physical, chemical, and biological. The most common physical methods of treatment of contaminated soils, such as disposal in a landfill, and incineration are expensive. Incineration is also a source of air pollution Chemical treatment includes direct injection of chemical oxidants into contaminated soil and groundwater thereby altering native aquatic chemistry. Biological treatment most commonly involves the breakdown of contamination into nontoxic forms using microbiological processes.
\end{abstract}

Key words: Petroleum, soil pollution, Leached, Hydrocarbons, Hazard Waste Management.

This paper has been presented at the International Symposium for Environmental Science and Engineering Research (ISESER), Konya, Turkey, 11-12 May 2018 